\title{
Physiological adaptations to high intertidal life involve improved water conservation abilities and metabolic rate depression in Littorina saxatilis
}

\author{
I. M. Sokolova ${ }^{1,2, *}$, H. O. Pörtner ${ }^{1}$ \\ ${ }^{1}$ Alfred-Wegener Institute for Polar and Marine Research, Columbusstrasse 3, 27568 Bremerhaven, Germany \\ ${ }^{2}$ White Sea Biological Station, Zoological Institute of Russian Academy of Sciences, Universitetskaya nab., 1, \\ 199034 St. Petersburg, Russia
}

\begin{abstract}
Mortality, rates of water loss, aerobic and anaerobic metabolic rates and changes in the parameters of cellular energy status were monitored in the intertidal gastropod Littorina saxatilis from different latitudes and shore levels during prolonged air exposure at elevated temperatures $\left(30^{\circ} \mathrm{C}\right)$. Prolonged air exposure, imitating environmental conditions during summer low tide at highshore levels, resulted in the onset of anaerobic metabolism, as indicated by the significant accumulation of succinate and alanine and a considerable depletion of high-energy phosphates (ATP and phospho-L-arginine, PLA). However, anaerobic metabolism accounted for only 1 to $2 \%$ of total ATP turnover in all groups, the remainder being supplied by aerobic metabolism. Snails from the White Sea population, which were more resistant to prolonged air exposure at $30^{\circ} \mathrm{C}$ than North Sea specimens, demonstrated higher anaerobic capacity and a depression of overall metabolic rate by ca $20 \%$ in air, whereas the less-resistant North Sea animals displayed very low anaerobic metabolic rates and elevated aerial oxygen consumption rates (110 to $125 \%$ of the rate observed in water). Within the White Sea population, high-shore periwinkles demonstrated higher resistance to prolonged air exposure than low-shore specimens associated with lower evaporation water loss, reduced rates of anaerobic ATP turnover, higher stores of L-aspartate and lower defended values of ATP and PLA. In contrast, no differences were found between high- and low-shore snails in the North Sea. This may reflect environmental conditions at the 2 study sites, with stronger contrasts between high- and low-shore habitats in the White Sea than in the North Sea. In general, our data show that adaptation to prolonged air exposure at elevated temperatures, which may occur at high-shore levels during summer low tide, does not necessarily involve increased anaerobic capacity in $L$. saxatilis. Instead, enhanced abilities for water conservation and metabolic rate depression combined with increased stores of fermentable substrate seem to be crucial for survival during prolonged periods of emersion.
\end{abstract}

KEY WORDS: Intertidal - Air exposure $\cdot$ Anaerobiosis $\cdot$ Respiration $\cdot$ Water loss $\cdot$ Metabolic rate Littorina saxatilis

Resale or republication not permitted without written consent of the publisher

\section{INTRODUCTION}

Intertidal animals inhabit a complex, variable and often unpredictable environment where they have to cope with periodic extreme events including summer heat or winter frost as well as desiccation and oxygen

\footnotetext{
${ }^{*}$ Present address: Department of Zoology, University of Guelph, Guelph, Ontario N1G 2W1, Canada.

E-mail: innas@bms.bc.ca
}

deficiency during low tide. The degree and duration of environmental stresses increase from low- to highshore levels (for a review see Raffaelli \& Hawkins 1996). At high-shore levels, the environmental conditions may not only become more extreme but are also characterised by high temporal instability and unpredictability. Numerous studies have shown that adaptation to life in the high intertidal may involve the increased thermal resistance of an organism (Stirling 1982, McMahon 1990, Sokolova et al. 2000a); heat 
stability of key metabolic enzymes (Hull et al. 1999, Sokolova \& Pörtner 2001); enhanced expression of heatshock proteins (Sanders et al. 1991, Tomanek \& Somero 1999, 2000); and morphological, behavioural and physiological adaptations ensuring increased extracorporal water storage, reduced evaporation and/or increased irradiative heat loss (Cleland \& McMahon 1986, McQuaid \& Scherman 1988, Britton \& McMahon 1990, McMahon 1990, Britton 1995, Sokolova et al. 2000a).

Owing to desiccation and temperature stresses, periods of emersion during low tide represent a major challenge to the metabolism of intertidal invertebrates. High temperatures during low tide may lead to increased metabolic rates and hence ATP demand, which may conflict with impaired oxygen uptake in air, especially in gill-breathing animals (McMahon 1988, 1992). Hence, efficient metabolic regulation should be crucial for survival. It has been shown that many intertidal animals are able to breathe air during low tide (Sandison 1966, Houlihan 1979, Innes \& Houlihan 1985, Marsden \& Weatherhead 1998). However, as desiccation progresses, animals may reduce oxygen uptake, in order to minimise evaporative water loss, and switch to anaerobiosis during prolonged air exposure (Houlihan 1979, Wieser 1980, Houlihan et al. 1981, Simpendörfer et al. 1995, 1997). Indeed, it has been shown that many (but not all) intertidal species accumulate anaerobic end products during prolonged air exposure (Wieser 1980, Vial et al. 1992, Grieshaber et al. 1994, Simpendörfer et al. 1995, 1997). Moreover, high-shore species or populations are usually characterised by a higher anaerobic potential compared to their low-shore or subtidal counterparts (de Vooys 1980, Bowen 1984, Sukhotin \& Pörtner 1999, Sokolova \& Pörtner 2001).

Although the capability of intertidal animals to survive anaerobiosis is generally recognised, the views concerning the potential role of aerobic and anaerobic metabolic pathways in supplying energy during air exposure are contradictory. Some authors suggest that aerobic metabolism dominates during air exposure in high intertidal animals (Houlihan 1979, Yipp et al. 1986, Simpendörfer et al. 1995), while others argue that aerobic metabolism in air is most important for low- and mid-shore animals, whereas high-shore invertebrates may rely more heavily on anaerobiosis during air exposure (Kronberg 1990, McMahon 1990). Until now there have been very few attempts to quantify the relative contribution of aerobic and anaerobic metabolism in supplying energy during air exposure in intertidal invertebrates (Shick et al. 1983, 1986). Moreover, although some earlier papers imply the deleterious effect of prolonged anaerobiosis during air exposure on substrate stores and energy balance in high-shore invertebrates (review in Newell 1979), no experimental studies concerning the effect of air exposure on cellular energy status in animals from different shore levels have been conducted. Hence it is not clear whether increased anaerobic capacity is generally involved in adaptation to air exposure or whether other mechanisms, which improve resistance to prolonged emersion (e.g. resistance to desiccation, increased aerobic capacity or enhanced metabolic rate depression), may be of primary importance.

The intertidal gastropod Littorina saxatilis has a wide vertical distribution occurring from the upper subtidal to the supratidal splash zone and thus encounters environments with greatly differing temperature and humidity regimes within the range of a single population (Sokolova et al. 2000a). This pattern allows us to compare animals adapted to life at different shore levels within ecologically, morphologically and genetically cohesive units such as a single species (or even a single population) and thus to avoid problems immanent to the interspecific comparison of environmental adaptation (Garland \& Adolf 1994). In our study, we investigated high- and low-shore animals in 2 populations of $L$. saxatilis from the sub-arctic White Sea and the temperate North Sea (Helgoland). The 2 study areas are separated by more than $10^{\circ}$ latitude and differ greatly in their climatic conditions. In general, seasonal and diurnal variations in temperature and humidity conditions and the contrasts between the environmental conditions of high- and low-shore are more pronounced at the White Sea site than at the North Sea site (see below). Hence, physiological differentiation along the vertical shore gradient of environmental conditions should be especially clearly manifested in White Sea populations of $L$. saxatilis compared to North Sea ones.

To study the role of metabolic regulation and water conservation abilities in the adaptation of Littorina saxatilis to high-shore habitats, we compared the rates of aerobic and anaerobic metabolism and ATP turnover and followed the time courses of mortality, evaporative water loss, anaerobic end-product accumulation and changes in the parameters of energy status in $L$. saxatilis from different latitudes and shore levels during prolonged air exposure at elevated temperature $\left(30^{\circ} \mathrm{C}\right)$, which imitates environmental conditions during summer low tide in the high intertidal. This investigation was intended to answer the following questions: (1) Does air exposure at elevated temperatures evoke anaerobiosis in L. saxatilis? What is the relative contribution of aerobic and anaerobic metabolism in supplying energy to the organism under these conditions? (2) Is anaerobic capacity limiting to the survival of L. saxatilis during prolonged air exposure? (3) Does differential resistance to prolonged air exposure at elevated temperatures correlate with the rates of water 
loss, with the rates of aerobic and anaerobic metabolism and/or with changes in cellular energy status?

\section{MATERIALS AND METHODS}

Collection sites and animals. Animals were collected in the intertidal zones of Kandalaksha Bay in the White Sea $\left(66^{\circ} 20^{\prime}\right.$ N, 33 $39^{\prime}$ E) in September 1999 and Helgoland in the North Sea (54 $11^{\prime}$ N, $7^{\circ} 53^{\prime} \mathrm{E}$ ) in October 1999 . The surface-water temperature was $10-12^{\circ} \mathrm{C}$ at both the White Sea and North Sea sites at the time of collection. The tidal range is $1.8-2.2 \mathrm{~m}$ at the White Sea sampling site and 1.6-2.8 $\mathrm{m}$ at the North Sea location. In general, sub-arctic White Sea populations of Littorina saxatilis experience extreme seasonal variations of temperature, from freezing (from below $-1.5^{\circ} \mathrm{C}$ in brackish seawater to between -10 and $-15^{\circ} \mathrm{C}$ in air) in late autumn and winter to $15-20^{\circ} \mathrm{C}$ and more in summer (Babkov 1998, Sokolova et al. 2000a). In contrast, both temperature fluctuations and temperature extremes are much less pronounced in the North Sea. Temperatures range from $3-6^{\circ} \mathrm{C}$ in winter to $15-18^{\circ} \mathrm{C}$ in summer (Hickel et al. 1997, Scharek et al. unpubl. data: available at http://www.pangaea.de). The monthly average temperature of surface water rarely ever drops below zero, and ice cover is rarely formed at the North Sea site. In contrast, ice cover at the White Sea may persist for ca $6 \mathrm{mo} \mathrm{yr}^{-1}$, and the monthly average temperature of surface water is negative for 5-6 mo (Babkov 1998). The annual average surfacewater temperatures are 4.3 and $10.4^{\circ} \mathrm{C}$ at the White Sea and North Sea sites, respectively.

In each study area, adult Littorina saxatilis (6-11 mm shell diameter) were collected from 2 contrasting shore levels: (1) low shore-from small stones and gravel patches in the low intertidal, within the brown macrophyte belt (Ascophyllum nodosum and Fucus vesiculosus in the White Sea and F. vesiculosus and F. serratus in the North Sea); and (2) high shore-in the narrow belt along the upper limit of $L$. saxatilis distribution on large boulders and/or rocks. At both study sites, highand low-shore habitats are separated by a distance of 15 to $20 \mathrm{~m}$ and differ greatly with respect to the duration of air exposure. The average duration of emersion varies between $10-40 \%$ and $75-90 \%$ of the total time for low- and high-shore animals, respectively (Sokolova et al. 2000a, I.M.S. pers. obs.). However, temperature and desiccation contrasts between high and low shores are greater for the White Sea population compared with that in the North Sea. During summer low tides, high-shore animals from the White Sea area experience wide temperature fluctuations, temperature extremes of up to $47^{\circ} \mathrm{C}$ and extreme desiccation stress while spending a long time (up to $7-8 \mathrm{~d}$ during neap tides) on dry rock surface (Sokolova et al. 2000a). In contrast, Helgoland animals may never be exposed to direct sunlight due to the shore morphology; so the differences in temperature fluctuations and temperature extremes between high- and low-shore habitats are small (Janke 1997, I.M.S. pers. obs.). Even during low tides, high-shore levels at the North Sea site receive water from either splash or land drainage; so there is little desiccation stress in these habitats (Janke 1997, I.M.S. pers. obs.). Hence, the contrasts of temperature and desiccation regimes between highand low-shore levels are much more pronounced in the White Sea than in the North Sea population despite similar positions relative to the mean low water mark and despite similar distances between the subpopulations from the 2 shore levels in each study area.

Snails were transported alive to the Alfred Wegener Institute (AWI) in Bremerhaven, Germany, and acclimated in aquaria with recirculated seawater set to the salinity of the respective sampling sites (33.2-33.4\%o for the North Sea and 24.6-24.7\% for the White Sea) for 4-6 wk prior to experimentation. Prolonged laboratory acclimation was used in order to eliminate the potential differences in physiology between the animals from different latitudes and shore levels, which were due to their recent acclimatisation history in the field. This allowed us to analyse irreversible (presumably, genetic) physiological differences between the compared groups of snails. Acclimation temperature $\left(12.5-13.0^{\circ} \mathrm{C}\right)$ was chosen close to the respective field temperature at the time of collection. Water was changed once every $2 \mathrm{wk}$. Brown macroalgae (Fucus vesiculosus) from Helgoland were added as a food source ad libitum. No mortality was detected during transportation, and only minimum mortality $(<5 \%)$ was detected during laboratory acclimation.

Aerial and aquatic respiration rates. Rates of aerial oxygen consumption were measured using fiber-optic oxygen sensors (micro-optodes) (Klimant et al. 1995) at $30^{\circ} \mathrm{C}$ in dried air, which imitated environmental conditions at high-shore levels during summer low tide (Sokolova et al. 2000a). Oxygen sensors with oxygensensitive fluorophor fixed on the tip of an optic fiber and connected to the instrument MICROX I (both manufactured by PreSens, Neuburg a.d. Donau, Germany) were used. MICROX I quantifies the phase-angle shift of emitted light based on oxygen-dependent dynamic quenching of luminescence (Klimant et al. 1995). Two point calibrations of temperature-equilibrated optodes (in air for $100 \%$ readings and in $100 \%$ nitrogen for $0 \%$ readings) were performed prior to and after each measurement in order to account for possible timedependent drifts of the optodes. Calibrations and all measurements were performed at a constant temperature $\left(30 \pm 0.1^{\circ} \mathrm{C}\right)$. 
Six to 10 animals of similar size (ranging from 40 to $50 \mathrm{mg}$ and from 80 to $120 \mathrm{mg}$ wet tissue weight [wet wt] from White and North Sea populations, respectively) were used for each measurement. An excess of desiccant (indicator silica gel) was placed on the bottom of an air-tight vial and covered with a nylon net ( $0.5 \mathrm{~mm}$ mesh size). Shells of the experimental snails were carefully scraped and cleaned with $95 \%$ ethanol to remove potential microfouling. Snails were allowed to quickly recover in seawater, blotted dry with tissue paper and put in the vial. The optode and a thermocouple connected to a PT100 thermometer (isiTEC, Bremerhaven, Germany) for temperature control were mounted in the gas-tight stopper. The vials were placed in a thermostatted water bath (HC F30, Julabo Labortechnik, Seelbach/Schwarzwald, Germany) and maintained at $30 \pm 0.1^{\circ} \mathrm{C}$ during the measurement. Oxygen concentration $\left(\left[\mathrm{O}_{2}\right]\right)$ was monitored online at 1 reading $\mathrm{min}^{-1}$. Preliminary experiments showed that exposure periods longer than $12-15 \mathrm{~h}$ resulted in mortality in some experimental chambers; so the measurements were carried out for 8-10 h. Afterwards specimens were taken out of the vial, placed in sea water at room temperature $\left(18-20^{\circ} \mathrm{C}\right)$ and allowed to recover for $2 \mathrm{~h}$. No mortality was detected during 8-10 h of air exposure at $30^{\circ} \mathrm{C}$.

Oxygen readings (\% air saturation) were recalculated as $\mathrm{mmol}^{-1} \mathrm{O}_{2}$ using the ideal gas law with van der Waals corrections (Radford 1964) considering the volumes of silica gel, snails and the nylon net determined by fluid displacement. To avoid potential errors in the determination of tissue wet weight due to water loss during air exposure, animals were weighed prior to the experiments to the nearest $0.1 \mathrm{mg}$. Tissue wet weight was calculated from the regressions of tissue wet weight and total body weight obtained separately for each experimental group (North Sea and White Sea specimens from high- and low-shore levels, respectively, data not shown).

The rates of oxygen consumption in water were measured in the closed respiration chambers with the Clarke-type electrodes connected to a $P_{\mathrm{O}_{2}}$ monitor (Eschweiler, Kiel, Germany). Two point calibrations of temperature-equilibrated optodes (in air-saturated sea water for $100 \%$ and in $\mathrm{Na}_{2} \mathrm{SO}_{3}$-saturated water for $0 \%$ readings) were performed prior to and after each measurement.

Five to 6 specimens of similar size (ranging from 40 to $50 \mathrm{mg}$ and from 80 to $120 \mathrm{mg}$ wet wt from White and North Sea populations, respectively) were used for each measurement. Shells of the experimental snails were cleaned as described above, snails were allowed to quickly recover, blotted dry with tissue paper and put in the chamber filled with the seawater at the temperature of acclimation $\left(12.5-13^{\circ} \mathrm{C}\right)$. Water in the chambers was continuously mixed with magnetic stirring rods, which were placed under the nylon net 'floor' $(0.5 \mathrm{~mm}$ mesh size) of the main chamber containing the specimens. Respiration chambers were placed in a thermostatted aquarium maintained at the control temperature $\left(12.5-13^{\circ} \mathrm{C}\right.$ ) and allowed to equilibrate for 20-30 $\mathrm{min}$ in order to minimise the effect of handling; temperature was raised at a rate of $1.5^{\circ} \mathrm{C} \mathrm{h}^{-1}$. The rate of temperature increase was set by the capacity of the thermostatted water bath. During this preliminary acclimation, a continuous flow of seawater was maintained through the experimental chambers. After the temperature reached $30^{\circ} \mathrm{C}$, the respiration chambers were closed and oxygen concentrations were monitored online for 15-25 min at a constant temperature $\left( \pm 0.1^{\circ} \mathrm{C}\right)$. A decline in the oxygen tension during the measurement did not exceed $15 \%$. After each measurement, blanks were run in the same chambers without specimens in order to account for the drift of electrodes and respiration of any microorganisms in the experimental chamber and seawater. Oxygen readings $\left(P_{\mathrm{O}_{2}}\right.$, torr) were recalculated as $\mu \mathrm{mol} \mathrm{l}^{-1}$ $\mathrm{O}_{2}$ considering the volumes of snails, stirring rods and nylon nets determined by fluid displacement. After the experiments, specimens were dissected in order to determine wet tissue weight and trematode infection. Due to a limited number of high-shore snails, only lowshore snails were used in this experiment. However, earlier studies performed on large data sets have shown that aquatic respiration rates do not differ in Littorina saxatilis from different shore levels acclimated to the same temperature in the laboratory (Sokolova 1997, Kaliberdina 1998). Hence, in this study the aquatic respiration rates of low-shore snails were considered representative for the whole population.

The different rates of temperature change in air and water used in our experiments were chosen in order to simulate the in situ rates of temperature change. During summer low tides at the White Sea, snails could be exposed to acute and drastic temperature change from $10-12^{\circ} \mathrm{C}$ in water to $30^{\circ} \mathrm{C}$ and more in air as the tide recedes. The body temperature of the snails follows the change in environmental temperature within several minutes under these conditions (Sokolova et al. 2000a). In water, the temperature usually changes much more slowly (I.M.S. pers. obs.). These differences were reflected in the slower rates of temperature change in water compared to the acute temperature change in air used in the present study.

Respiration rates were expressed as $\mu \mathrm{mol} \mathrm{O}_{2} \mathrm{~h}^{-1} \mathrm{~g}^{-1}$ wet wt. In the determinations of aquatic and aerial respiration rates, infested and uninfested specimens were pooled, since it has already been demonstrated that infection by microphallids (Trematoda) does not influence respiration rate of Littorina spp. (Lyzen et al. 1992, Sokolova 1997). 
Evaporative water loss. This was measured according to a method modified from McMahon \& Britton (1985). Snails of similar shell size (5.5-6.3 mm shell diameter) were taken out of the aquaria and blotted dry with tissue paper. The snails were weighed to the nearest $0.025 \mathrm{mg}$ and placed individually in the cells of 40 -cell wells thermostatted to $30 \pm 0.25^{\circ} \mathrm{C}$. Excess desiccant (indicator silica gel) was added to ensure dry conditions in the experimental chambers. After specified exposure periods $(6,12,24$ or $48 \mathrm{~h})$ snails were taken out of the thermostat chambers and weighed. Then snails were placed in seawater, allowed to recover for $2 \mathrm{~h}$ and scored for mortality. After scoring, snails were dried at $100^{\circ} \mathrm{C}$ for $24 \mathrm{~h}$ to constant weight, allowed to cool down in the presence of desiccant and weighed. For each shore level in each population, 30-55 specimens were initially included in the experiment. However, the number of the individuals used in the final analysis varied as only survivors were used.

Water loss was determined as a percentage of the total (corporal + extracorporal) body water:

$$
W L=\frac{W_{\text {in }}-W_{\text {exp }}}{W_{\text {in }}-W_{\text {dry }}} \times 100 \%
$$

where $W L$ is water loss (\%), $W_{\text {in }}, W_{\text {exp }}$ and $W_{\text {dry }}$ are initial weight, weight after a given exposure period and final dry weight of a snail (mg), respectively. The initial amount of body water (calculated as $W_{\text {in }}-W_{\text {dry }}$ ) was similar in high- and low-shore specimens within each studied population (Student's $t$-test, $\mathrm{p}>0.05$, data are not presented). Preliminary experiments showed that the rate of evaporative water loss did not differ significantly between the non-infested snails and those infested by the microphallids (data not shown); hence the data for infested and uninfected specimens were pooled for subsequent analysis.

Metabolite analysis. For the determination of metabolite concentrations during air exposure at elevated temperature, specimens were exposed for $2,4,6$, 12 (13), 24 or $48 \mathrm{~h}$ at $30^{\circ} \mathrm{C}$ in dried air (Sokolova et al. 2000a). For this, snails were taken from the acclimation aquaria, briefly blotted dry with tissue paper and placed in plastic Petri dishes. Each Petri dish contained 50-70 specimens. The Petri dishes were placed into desiccators on top of excess desiccant to ensure dry conditions. The desiccators were kept at $30 \pm 0.25^{\circ} \mathrm{C}$. After specified exposure periods, a number of the snails were removed, dissected and quickly inspected for trematode infestation. Infested specimens were discarded. In uninfested ones, the foot muscle was quickly cut, blotted dry with tissue paper and frozen immediately in liquid nitrogen for subsequent metabolite analyses. For control samples, specimens were taken directly from the acclimation aquaria, they were blotted dry and the foot muscles were sampled as described above. For 1 sample, tissues from 8-12 specimens were pooled.

For the determination of metabolite concentrations, samples of foot muscle were powdered with a pestle and mortar under liquid nitrogen. Circa $300 \mathrm{mg}$ of tissue powder were homogenised in an excess $(5 \times)$ volume of precooled $0.6 \mathrm{~mol} \mathrm{l}^{-1}$ PCA with $10 \mathrm{mmol} \mathrm{l}^{-1}$ EDTA. Precipitated protein was removed by centrifugation. The extract was neutralised with $5 \mathrm{mmol} \mathrm{l}^{-1}$ potassium hydroxide to $\mathrm{pH} 7.0-7.5$. Precipitated potassium perchloride was removed by a second centrifugation. Extracts were stored at $-80^{\circ} \mathrm{C}$.

In preliminary assays, concentrations of succinate, lactate, acetate and propionate in PCA extracts were measured according to a method modified from that in Hardewig et al. (1991). Fatty acids were separated on an ion exclusion column (Dionex ICE-AS 1) at a flow rate of $1 \mathrm{ml} \mathrm{min}^{-1}$ and $40^{\circ} \mathrm{C}$ with $0.125 \mathrm{mmol} \mathrm{l}^{-1}$ heptafluorobutyric acid used as an eluent. Peaks were monitored with a conductivity detector. A micro membrane suppressor (Dionex AMMS-ICE) was used to decrease background conductivity. Only succinate and (in 1 sample) lactate was found in concentrations close to the detection limit of the method employed. Therefore, succinate, D-lactate and L-lactate were further determined spectrophotometrically using the respective enzymatic tests (Bergmeyer 1985). Tissue levels of AMP, ADP, ATP, L- and D-alanine and L-aspartate were also measured enzymatically according to Bergmeyer $(1985 a, b)$. Concentrations of phospho-L-arginine and L-arginine were assayed spectrophotometrically using the enzymatic test described by Grieshaber et al. (1978). Octopine dehydrogenase for these determinations was purified from the adductor muscles of Pecten maximus following the procedure described by Gäde \& Carlsson (1984). All metabolite concentrations were corrected for the respective tissue water loss, and corrected values were used for subsequent calculations and statistical analysis.

Chemicals. All chemicals were purchased from Sigma Chemical Co. (St. Louis, MO) or Merck (Darmstadt, Germany). Enzymes were purchased from Roche Diagnostics (Mannheim, Germany).

Derived indices. The relative amount of phosphagen $\left(R_{\text {PLA }}\right)$ was calculated according to

$$
R_{\mathrm{PLA}}=\frac{[\mathrm{PLA}]}{[\mathrm{PLA}]+[\mathrm{Arg}]}
$$

where [PLA] and [Arg] are tissue concentrations of phospho-L-arginine and L-arginine, respectively ( $\mu \mathrm{mol}$ $\mathrm{g}^{-1}$ wet wt).

The rate of ATP turnover during anaerobiosis (amount of ATP consumed $\mathrm{g}^{-1}$ wet wt $\mathrm{d}^{-1}, M_{\mathrm{ATP}}$ ) was calculated from end product accumulation and ATP and PLA depletion as described in Pörtner et al. (1984). 
The following values for ATP equivalents were used: $2.75 \mu \mathrm{mol} \mu \mathrm{mol}^{-1}$ succinate and $1.5 \mu \mathrm{mol} \mu \mathrm{mol}^{-1}$ alanine (de Zwaan 1983). Aspartate depletion was not considered in these calculations, which might result in some overestimation of the rates of anaerobic ATP turnover. However, because the main energy supplying pathways during air exposure in Littorina saxatilis were aerobic (see below), a different stoichiometry between aspartate depletion and succinate and alanine accumulations might be expected compared to fully anaerobic conditions (de Zwaan 1983). Because the true stoichiometry between aspartate depletion and succinate and alanine accumulations under predominantly aerobic conditions is unknown, we used the maximised anaerobic ATP turnover rates as a rough estimate of the anaerobic $M_{\text {ATP. The aerobic }}$
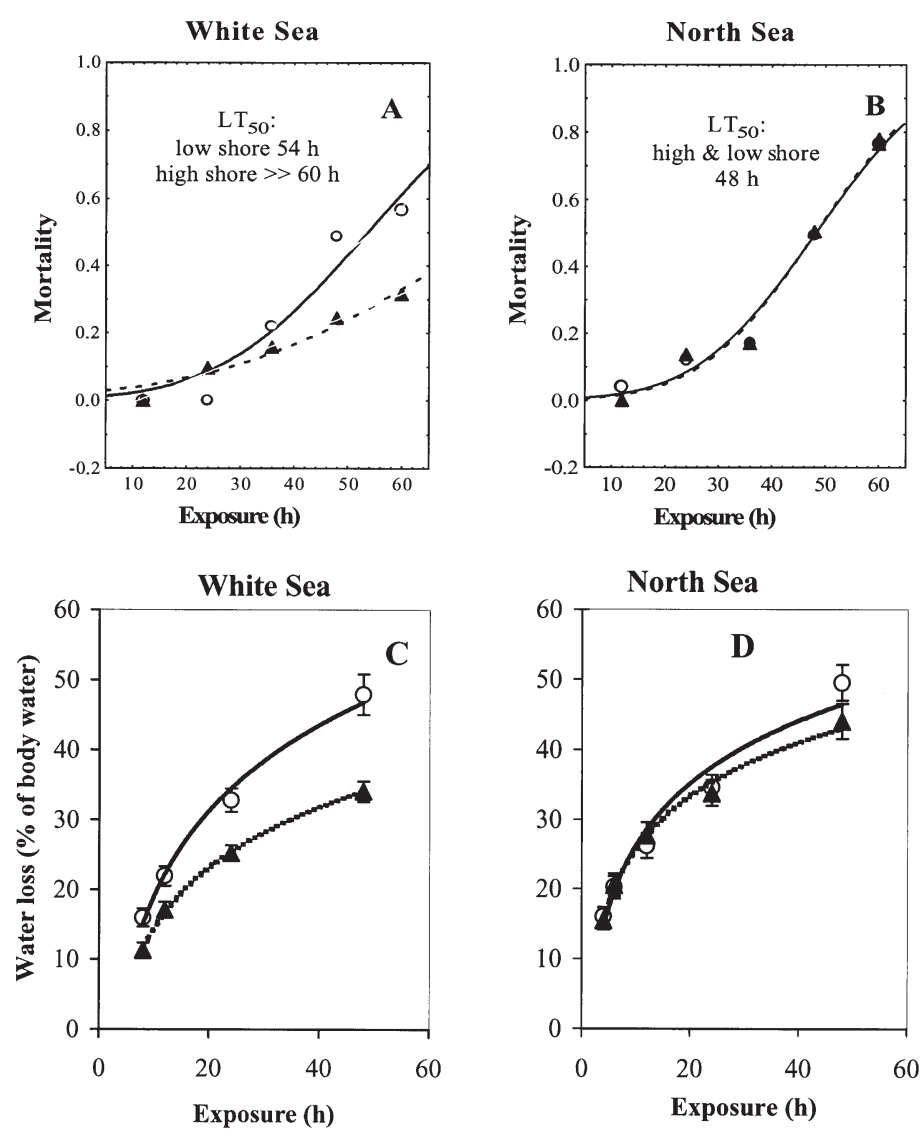

Shore level: $\quad$ O low $\Delta$ high

Fig. 1. Littorina saxatilis. $(\mathrm{A}, \mathrm{B})$ Mortality and $(\mathrm{C}, \mathrm{D})$ evaporative water loss during air exposure at $30^{\circ} \mathrm{C}$ in snails from different shore levels in the White and North Seas. For an estimation of mortality rates, probit-regressions were constructed by an iterative, quasi-Newton procedure with a maximum likelihood loss function. $\mathrm{N}=50-120$ ind. in each group for each exposure time. $\mathrm{LT}_{50}$ : time of $50 \%$ mortality. Rates of water loss were approximated by exponential regressions.

$$
\mathrm{N}=10-30
$$

ATP turnover rate was calculated from routine oxygenconsumption rates assuming ATP production at $6 \mathrm{~mol}$ ATP mol $^{-1} \mathrm{O}_{2}$.

Statistics. Statistical comparisons of respiration rates, metabolite concentrations, rates of ATP turnover and $R_{\text {PLA }}$ at different exposure times in snails from different shore levels were performed using standard 2-way mixed model ANOVAs after testing the assumptions of normal distribution and homogeneity of variances of the data (Sokal \& Rohlf 1995). The factor 'Shore level' was treated as fixed, 'Exposure duration' as random. We used Tukey's honestly significant difference (HSD) test for unequal $\mathrm{N}$ as a method of post-hoc comparisons and Fisher's least significant difference (LSD) tests for planned comparisons. In cases where factor interactions were significant, 1-way ANOVAs were performed separately for each factor. Mortality rates in Littorina saxatilis were compared using log-linear models of analysis of contingency tables (Sokal \& Rohlf 1995). Probit-regressions used for calculations of the time of $50 \%$ mortality $\left(\mathrm{LT}_{50}\right)$ were constructed by an iterative, quasi-Newtonian procedure with maximum likelihood loss estimate of the model parameters (Sokal \& Rohlf 1995). A maximum of 20 iterations was required for the convergence of parameters. To compare the rates of water loss in snails from different shore levels, linear regressions of log-transformed values of water loss versus log-transformed time of exposure were constructed. Parameters of linear regressions were calculated according to Sokal \& Rohlf (1995), and the fitting of the data into the linear regression model was estimated by ANOVA. Pairwise comparison of slope and intercept of regression lines was performed according to the algorithm described in Urbakh (1964). The differences were considered significant if the probability level of a Type I error was less than 0.05 . Results are expressed as percentages or mean $\pm \mathrm{SE}$ if not mentioned otherwise.

\section{RESULTS}

\section{Mortality and evaporative water loss}

Log-linear analysis showed that in the White Sea population, high-shore specimens were significantly more resistant to air exposure at $30^{\circ} \mathrm{C}$ than their lowshore counterparts (partial association: $\chi^{2}=25.1, \mathrm{df}=1$, $\mathrm{p}<0.001$ ) (Fig. 1A). In North Sea Littorina saxatilis, no significant differences in mortality rates were found between high- and low-shore periwinkles (partial association: $\chi^{2}=0.004$, df $=1, p=0.95$ ) (Fig. 1B). The mortality rates in North Sea L. saxatilis were higher than in their White Sea counterparts, with an $\mathrm{LT}_{50}$ of 48, 54 and $\gg 60$ h for North Sea, low-shore White Sea 
and high-shore White Sea specimens, respectively. Trematode infection had no significant effect on the mortality rates during air exposure at $30^{\circ} \mathrm{C}$ in both North Sea and White Sea L. saxatilis (Yates-corrected $\chi^{2}$ values of $0.02-1.73, \mathrm{df}=1, \mathrm{p}=0.18-0.92$ ).

Water loss was non-linear in Littorina saxatilis and occurred much faster during the first $12 \mathrm{~h}$ of air exposure than during the following $36 \mathrm{~h}$ (Fig. 1C,D). In White Sea L. saxatilis, high-shore specimens were able to conserve body water reserves better than their lowshore counterparts $(t=2.84$, df $=154, \mathrm{p}<0.05$ for differences in the rates of water loss). As a result, after $48 \mathrm{~h}$ of air exposure at $30^{\circ} \mathrm{C}$, high-shore snails lost ca $34 \%$ of the total body water, while those from the low-shore level lost $48 \%$ of their body water reserves. In North Sea periwinkles, the rates of water loss were similar in high- and low-shore specimens $(t=1.40, \mathrm{df}=$ 128, $\mathrm{p}>0.05)$. Also, rates of water loss in North Sea L. saxatilis were similar to those of low-shore snails from the White Sea. After $48 \mathrm{~h}$ of air exposure at $30^{\circ} \mathrm{C}$, they lost $44-49 \%$ of the body water.

\section{Aerial respiration}

Littorina saxatilis was found to consume atmospheric oxygen at a considerable rate under conditions of air exposure at elevated temperatures. Rates of aerial oxygen consumption $\left(\dot{V}_{\mathrm{O}_{2}}\right)$ during the first 8-10 h of exposure at $30^{\circ} \mathrm{C}$ ranged from 2.63 to $9.25 \mu \mathrm{mol} \mathrm{O} \mathrm{O}^{-1} \mathrm{~h}^{-1}$ and were similar in snails from the White and North Seas $\left(F_{1,17}=0.70, \mathrm{p}=0.41\right)$ and from high- and lowshore levels $\left(F_{1,17}=0.93, \mathrm{p}=0.35\right)$ (Fig. 2). In both populations studied, high-shore snails tended to have somewhat lower respiration rates under these conditions, although this trend was not significant. In White Sea L. saxatilis, mean aerial $V_{\mathrm{O}_{2}}$ was by $15-20 \%$ lower than the rate of aquatic $V_{\mathrm{O}_{2}}$ at a similar temperature. In contrast, in North Sea snails aerial respiration rates exceeded the rate of aquatic $V_{\mathrm{O}_{2}}$ by $12-25 \%$. There was a tendency for aerial $V_{\mathrm{O}_{2}}$ to decrease after prolonged (more than 12-15 h) air exposure at elevated temperatures possibly due to the progressive loss of water from the mantle cavity. However, this phenomenon could not be followed quantitatively due to the onset of mortality in some experimental chambers after $12 \mathrm{~h}$ of air exposure.

\section{Anaerobic end-product accumulation}

Despite their marked ability to breathe air, Littorina saxatilis became partly anaerobic during air exposure at elevated temperatures, as indicated by the significant accumulation of anaerobic end products. Of all

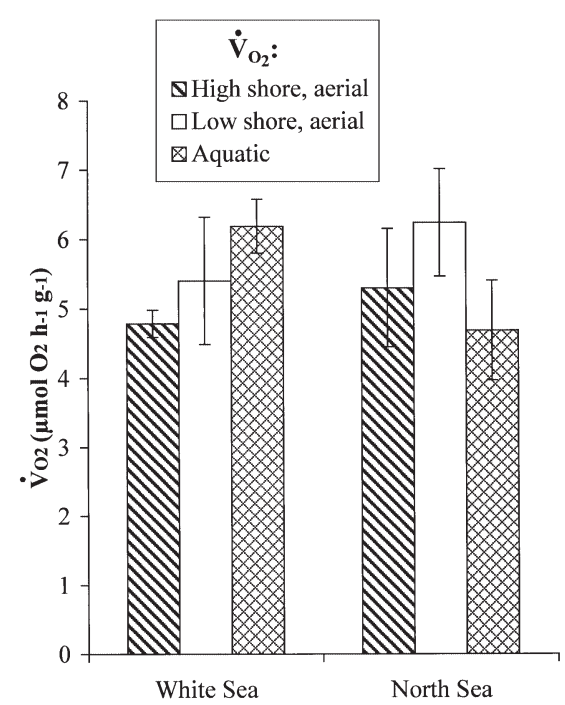

Fig. 2. Littorina saxatilis. Rates of aquatic and aerial oxygen consumption during air exposure at $30^{\circ} \mathrm{C}$ in snails from different shore levels in the North and White Seas. Aerial oxygen consumption $\left(V_{\mathrm{O}_{2}}\right)$ was determined during the first 8-10 h of exposure in dried air. $\mathrm{N}=4-7$. Differences in aerial $V_{\mathrm{O}_{2}}$ between the specimens from different shore levels were statistically non-significant ( $\mathrm{p}>0.1$ )

anaerobic end products tested, only succinate and D- and L-alanine accumulated during air exposure at $30^{\circ} \mathrm{C}$ in L. saxatilis. Levels of other end products (D- and L-lactate, acetate and propionate) were below detection limits of the methods in controls and after prolonged air exposure.

Alanine was the major anaerobic end product accumulated in Littorina saxatilis during air exposure at $30^{\circ} \mathrm{C}$. Notably, L- and D-stereoisomers of this amino acid were found in approximately equimolar amounts (average ratio of L- to D-alanine was $1.1 \pm 0.3, \mathrm{~N}=125$ ), suggesting the presence of an amino acid racemase in the foot muscle of L. saxatilis. Control levels of L- and D-alanine in the foot muscles were significantly higher in North Sea specimens than in their White Sea counterparts $\left(F_{1,19}=10.79, \mathrm{p}=0.004\right)$ (Fig. 3A). In general, alanine concentrations increased by ca $5 \mu \mathrm{mol} \mathrm{g}^{-1}$ wet wt over the respective control levels after $24-48 \mathrm{~h}$ of air exposure in White Sea snails. In contrast, highshore L. saxatilis from the North Sea accumulated considerably less alanine, and in low-shore periwinkles from this area no alanine accumulation was observed (Fig. 3B).

Succinate concentrations in Littorina saxatilis foot muscles rose significantly during prolonged air exposure at $30^{\circ} \mathrm{C}$, although to a far lesser extent than alanine levels (Fig. 3C,D). Generally, succinate accumulation was higher in White Sea specimens (ca 0.4-0.5 $\mathrm{mmol} \mathrm{g}^{-1}$ wet wt) than in their conspecifics from 
the North Sea (ca $0.2-0.4 \mu_{m o l ~ g}{ }^{-1}$ wet wt). Similar to alanine, succinate levels of the foot muscle increased significantly in both high- and low-shore specimens from the White Sea, but only in high-shore ones from the North Sea (Fig. 3C,D). Comparisons between shore
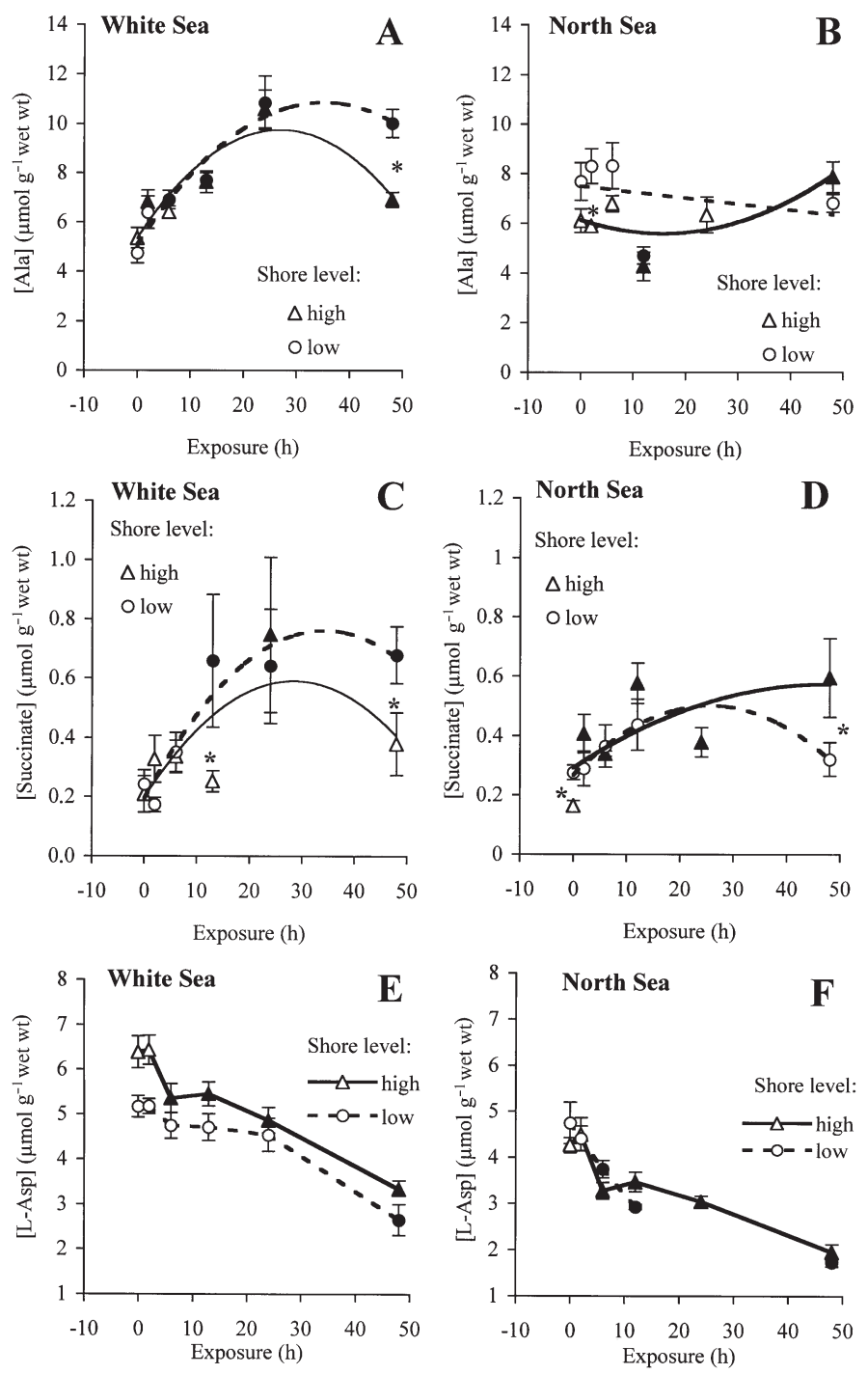

Fig. 3. Littorina saxatilis. Accumulation of anaerobic end products (alanine and succinate) and depletion of L-aspartate stores in the foot muscle of snails from different shore levels in the North and White Seas during air exposure at $30^{\circ} \mathrm{C}$. The time course of endproduct accumulation (A-D) was approximated by second-order polynomial regressions. Asterisks (*) mark significant differences between concentrations of the respective end products in the foot muscle tissue of high- and low-shore snails calculated by post-hoc tests in cases where estimates of single-factor effects were impossible due to significant factor interactions. Aspartate concentrations differed significantly between high- and low-shore snails from the White Sea $\left(F_{1,5}=30.68, \mathrm{p}=0.003\right)$ but not between those from the North Sea $\left(F_{1,4}=0.03, \mathrm{p}=0.86\right)$. Solid symbols mark the values which are significantly different from the respective controls $(\mathrm{p}<$ 0.05). $\mathrm{N}=5-8$ for controls and $12-48 \mathrm{~h}$ of exposure and $3-7$ for 2 and $6 \mathrm{~h}$ of exposure levels demonstrated that high-shore specimens from the White Sea accumulated significantly less alanine and succinate in the foot muscle than their lowshore counterparts after 12 and $48 \mathrm{~h}$ of air exposure (Fig. 3A,C). In North Sea L. saxatilis, differences in the levels of accumulated anaerobic end products showed no consistent pattern between high- and low-shore specimens. Succinate accumulation was higher in high-shore than in low-shore specimens from the North Sea, whereas concentrations of alanine were similar in snails from different shore levels (Fig. 3B,D).

\section{Aspartate depletion}

Concentrations of L-aspartate in the foot muscle tissues decreased significantly in all experimental groups of Littorina saxatilis during air exposure at $30^{\circ} \mathrm{C}$ (Fig. 3E,F). In White Sea L. saxatilis, significant differences in L-aspartate levels of the muscle tissue were found between high- and low-shore specimens (Fig. 3E). High-shore periwinkles from the White Sea population tended to have a higher content of L-aspartate in the foot muscle tissue than their low-shore counterparts both in controls and after prolonged air exposure at elevated temperatures. In contrast, L-aspartate content of the muscle tissue was similar in high- and low-shore specimens from the North Sea (Fig. 3F).

\section{High-energy compounds}

Initial (control) values of ATP were similar in the foot muscles of the snails from the North and White Seas and varied between 2.2 and $2.5 \mu \mathrm{mol}$ $\mathrm{g}^{-1}$ wet wt $\left(F_{1,19}=0.56, \mathrm{p}=0.46\right)$ (Fig. 4A,B). In contrast, control North Sea Littorina saxatilis had significantly higher PLA levels in the foot muscle (3.7-3.8 $\mu \mathrm{mol} \mathrm{g}^{-1}$ wet wt) than their White Sea counterparts $\left(2.5-3.2 \mu \mathrm{mol} \mathrm{g}{ }^{-1}\right.$ wet wt) $\left(F_{1,18}=\right.$ 10.10, p $=0.005)$. Control concentrations of the respective aphosphagen (L-arginine) as well as the total amount of phosphagen and aphosphagen were also 1.5-2 times higher in the foot muscles of the North Sea periwinkles (3.2-3.3 and 6.9-7.1 $\mu \mathrm{mol} \mathrm{g}{ }^{-1}$ wet wt for L-arginine and phosphagen/aphosphagen, respectively) than in those of their White Sea counterparts (1.7-2.6 and $4.2-5.8 \mu \mathrm{mol} \mathrm{g}{ }^{-1}$ wet wt for L-arginine and phosphagen/aphosphagen, respectively). However, the ratio between phosphagen and aphosphagen was similar in L. saxatilis from the 2 seas $(54-60 \%)\left(F_{1,19}=3.90, \mathrm{p}=0.064\right)$. 
Combined desiccation and high-temperature stresses resulted in impaired cellular energy status in Littorina saxatilis (Fig. 4A, $\mathrm{B}, \mathrm{E}, \mathrm{F}$ ). In the White Sea population, low-shore specimens tended to maintain significantly higher levels of ATP and PLA than their high-shore counterparts in controls and after prolonged air exposure (Fig. 4A,E). In the North Sea
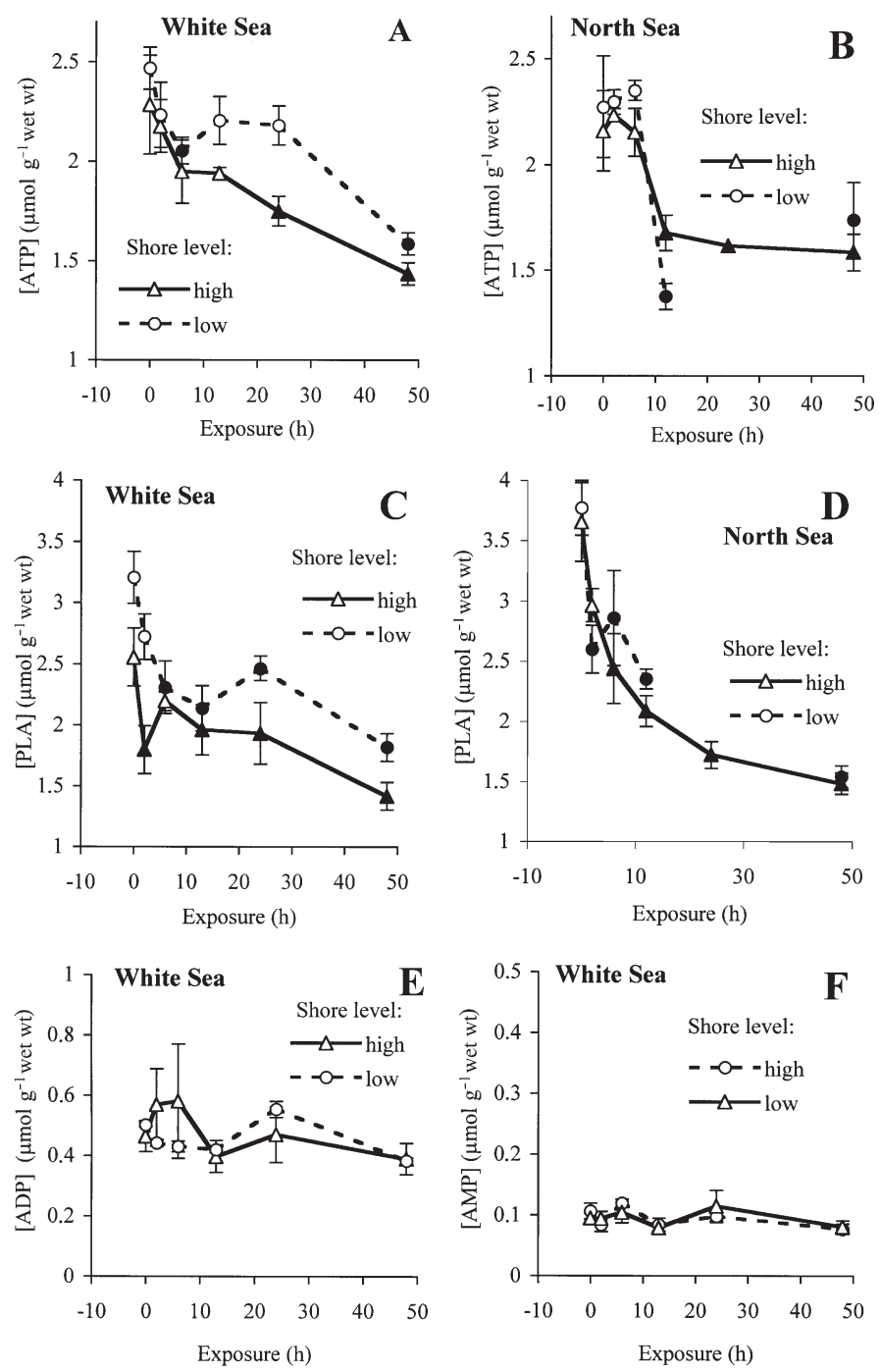

Fig. 4. Littorina saxatilis. Changes in the concentration of highenergy phosphates (adenylates and phospho-L-arginine) in the foot muscle of snails from different shore levels in the North and White Seas during air exposure at $30^{\circ} \mathrm{C}$. Concentrations of high-energy phosphates differed significantly between high- and low-shore specimens from the White Sea $\left(F_{1,5}=16.66, \mathrm{p}=0.01\right.$ and $F_{1,5}=$ $16.45, \mathrm{p}=0.01$ for ATP and PLA, respectively) but not between those from the North Sea $\left(F_{1,4}=0.20, \mathrm{p}=0.69\right.$ and $F_{1,4}=0.85, \mathrm{p}=$ 0.41 for ATP and PLA, respectively). Levels of ADP and ATP did not differ between specimens from different shore levels $\left(F_{1,5}=0.36\right.$, $\mathrm{p}=0.57$ and $F_{1,5}=0.004, \mathrm{p}=0.95$ for ATP and PLA, respectively). Solid symbols mark the values which are significantly different from the respective controls $(\mathrm{p}<0.05)$. $\mathrm{N}=5-8$ for controls and 12-48 $\mathrm{h}$ of exposure and $3-7$ for 2 and $6 \mathrm{~h}$ of exposure population, no differences were found between specimens from different shore levels with respect to the concentrations of ATP and PLA in the foot muscle (Fig. 4B,F). In White Sea specimens, levels of ADP and AMP were similar in the foot muscles of snails from different shore levels and remained unaffected by air exposure (Fig. 4C,D).

Despite significant depletion of PLA, concentrations of L-arginine did not change significantly during air exposure at elevated temperatures in White Sea periwinkles and even decreased in North Sea ones (Fig. 5A,B), suggesting that this amino acid is either excreted or further metabolised. Accordingly, a decline in the sum of PLA and L-arginine as well as in $R_{\mathrm{PLA}}$ reflected depletion of PLA during air exposure (Fig. 5C-F).

\section{Aerobic and anaerobic ATP turnover rates}

Average rates of aerobic ATP turnover $\left(M_{\mathrm{ATP}}\right)$ were similar in specimens from different seas and shore levels (Fig. 6A) and ranged between 28.7 and $37.5 \mu \mathrm{mol}$ of ATP equivalents $\mathrm{h}^{-1} \mathrm{~g}^{-1}$ wet wt. Aerobic $M_{\mathrm{ATP}}$ tended to be lower in air than in water in White Sea Littorina saxatilis, but a reverse pattern was observed in North Sea specimens, reflecting different ratios of aerial to aquatic respiration rates in specimens from the 2 seas (see above). Anaerobic rates of ATP turnover were low (Fig. 6A) and accounted for only 1-2\% of the total rate of ATP turnover. The rate of anaerobic $M_{\text {ATP }}$ decreased during prolonged air exposure in White Sea and North Sea L. saxatilis, suggesting depression of the anaerobic metabolic rate (Fig. 6B). In White Sea specimens, rates of anaerobic ATP turnover were lower in high-shore specimens as compared to their low-shore counterparts (Fig. 6B). In contrast, anaerobic ATP turnover rates did not differ in high- and lowshore snails from the North Sea to up to $13 \mathrm{~h}$ of air exposure. However, $M_{\text {ATP }}$ calculated for the overall $48 \mathrm{~h}$ period of exposure was significantly lower in low-shore periwinkles from the North Sea than in their high-shore counterparts. This reflects the absence of significant accumulation of anaerobic end products in low-shore specimens during $48 \mathrm{~h}$ of air exposure (see above) (Fig. 6B).

\section{DISCUSSION}

Physiological functions of Littorina saxatilis during low tide may be jeopardised by several interacting factors, of which desiccation, extreme tem- 

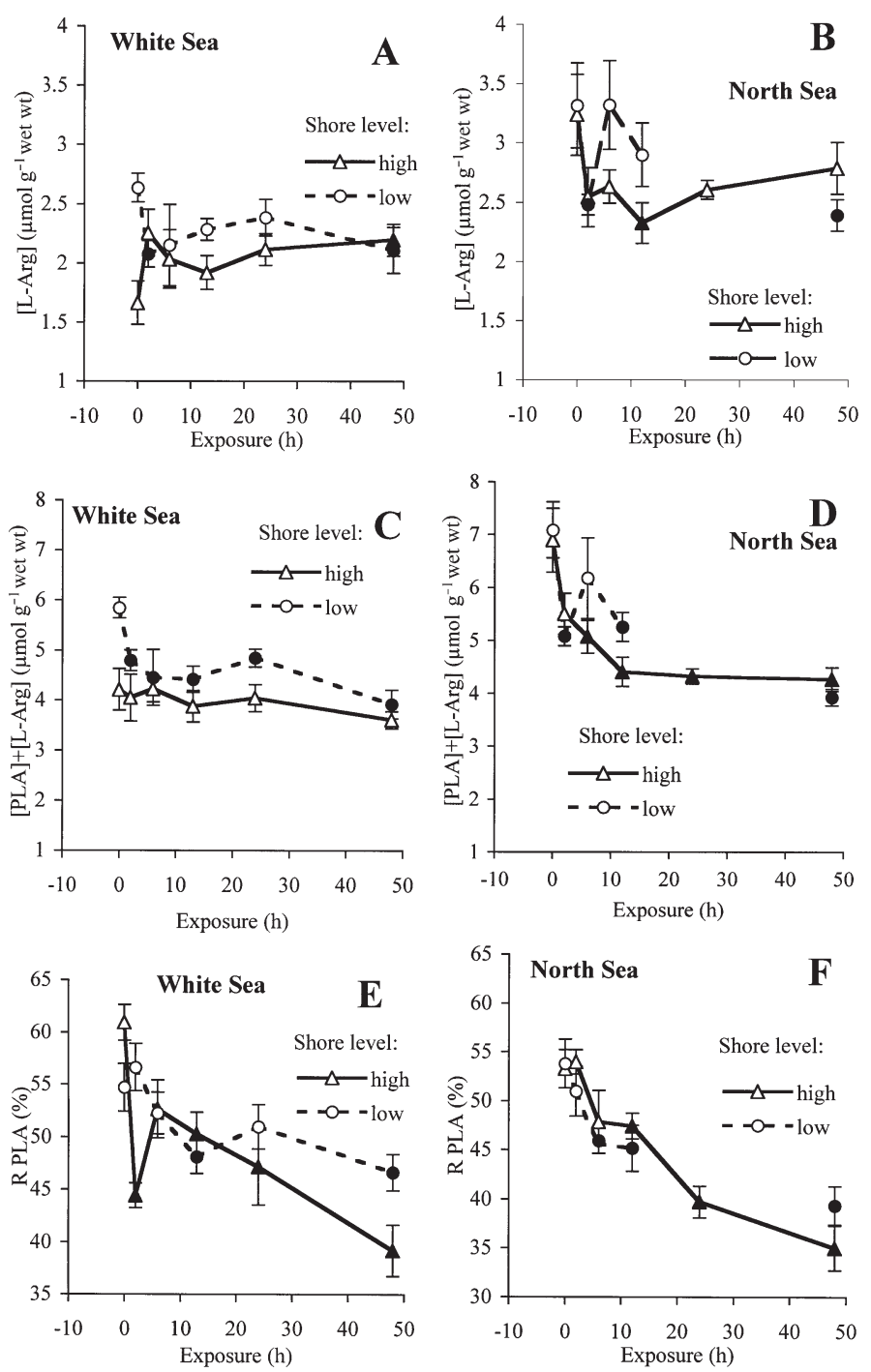

Fig. 5. Littorina saxatilis. Changes in the concentration of L-arginine, the sum of phosphagen and aphosphagen concentrations and the ratio of phospho-L-arginine in the total phosphagen/aphosphagen pool $\left(R_{\mathrm{PLA}}\right)$ in the foot muscle of snails from different shore levels in the North and White Seas during air exposure at $30^{\circ} \mathrm{C}$. The sum of phosphagen and aphosphagen concentrations differed significantly between high- and low-shore specimens from the White Sea $\left(F_{1,5}=\right.$ $10.89, \mathrm{p}=0.021)$ but not between those from the North Sea $\left(F_{1,4}=\right.$ $0.63, \mathrm{p}=0.47$ ). Differences in L-arginine concentrations and $R_{\mathrm{PLA}}$ between high- and low-shore specimens were non-significant (ANOVA, $p>0.4$ ). Solid symbols mark the values which are significantly different from the respective controls $(\mathrm{p}<0.05)$. $\mathrm{N}=5-8$ for controls and $12-48 \mathrm{~h}$ of exposure and $3-7$ for 2 and $6 \mathrm{~h}$ of exposure

peratures and oxygen deprivation are of major importance. These stresses may have synergistic negative effects on survival and/or performance of the snails during prolonged emersion. That is why it could be expected that adaptation to high-shore life involves adjustments of several important physiological functions, including characteristics of water economy, tem- perature resistance and metabolic regulation. Comparison of these parameters in L. saxatilis subpopulations from different habitats, which demonstrate differential resistance to prolonged air exposure, desiccation and high-temperature stresses, allows us to determine the crucial physiological mechanisms playing the foremost role in adaptation to high-shore life in these intertidal gastropods.

Differential resistance to prolonged air exposure at elevated temperatures was notably correlated with water conservation ability in Littorina saxatilis. The most resistant group (high-shore specimens from the White Sea) had the lowest rates of water loss during air exposure, whereas the least resistant North Sea specimens tended to loose body water at much higher rates. The correlation coefficient between $\mathrm{LT}_{50}$ and the rate of water loss was highly negative $(r=-0.925)$ and marginally significant even despite the low degrees of freedom $(p=0.07, N=4)$. In general, increased resistance to prolonged air exposure and desiccation stress is frequently associated with improved water conservation abilities in high intertidal species and/or (sub-) populations of marine invertebrates, so that reduced evaporation rates seem to be crucial in the adaptation to the upper shore with high risk of desiccation (Broekhuysen 1940, Brown 1960, Davies 1969, McMahon 1990, Sokolova et al. 2000a). Interestingly, similar findings have been reported for several Drosophila species from natural and laboratory populations. In nature, desert flies lost water less rapidly and were more tolerant of desiccation than Drosophila spp. from mesic habitats. However, flies from different habitats contained similar amounts of bulk water (Gibbs 1999). In contrast, selection in an 'artificial desert' in the lab resulted in lines of D. melanogaster and D. simulans that had lower rates of water loss and carried $30 \%$ more water than their controls but did not differ in desiccation tolerance (Gibbs 1999). Thus, the only component of the water budget showing similar differentiation in the field and in the lab was reduced rates of water loss in xeric-adapted specimens, which further emphasises the importance of water conservation in habitats with high desiccation stress.

In intertidal shelled molluscs and barnacles, reduced evaporation rates are usually achieved by means of a tight closure of shell valves or operculum, which ensures isolation from the hostile environment during the low tide (Newell 1979, Shick et al. 1988). However, this behaviour also reduces oxygen supply to tissues unless a considerable amount of gaping (inevitably 

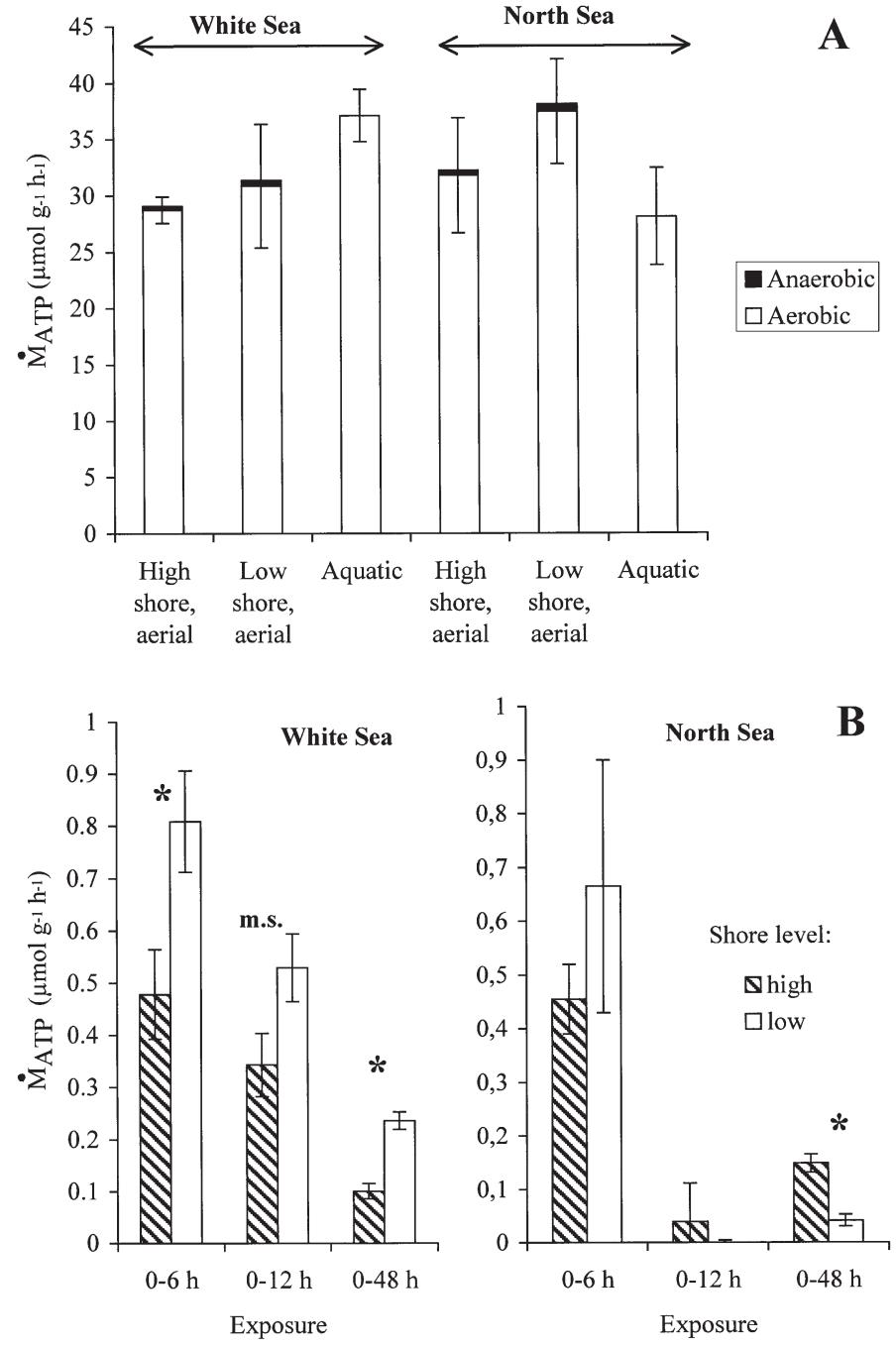

Fig. 6. Littorina saxatilis. Rates of $(\mathrm{A})$ aerobic and $(\mathrm{A}, \mathrm{B})$ anaerobic ATP turnover in the foot muscle of snails from different shore levels in the North and White Seas in water and during air exposure at $30^{\circ} \mathrm{C}$. (A) Rates of aerobic and anaerobic ATP turnover in water and during the first $8-10 \mathrm{~h}$ of air exposure. Note that anaerobic $M_{\text {ATP }}$ does not exceed $2 \%$ of the aerobic ATP turnover. (B) Rates of anaerobic ATP turnover calculated over different periods of air exposure at $30^{\circ} \mathrm{C}$. Asterisks (*) mark significant differences in the rates of anaerobic ATP turnover between high- and low-shore snails $(p<0.05)$. m.s.: marginally significant $(p=0.07)$

linked to water loss) occurs (Shick et al. 1986, 1988). Indeed, the higher rates of oxygen consumption in the studied Littorina saxatilis tended to be associated with increased water loss during the first hours of air exposure (Pearson's $\mathrm{R}=0.860$ ), although this relationship was not statistically significant due to the small number of groups compared ( $\mathrm{p}=0.14, \mathrm{~N}=4)$. As a result, in order to save water, many intertidal species may become partially anaerobic during air exposure at low tide (Shick et al. 1988, McMahon 1990). In fact, accumulation of anaerobic end products during prolonged air exposure was found in L. saxatilis in this study and has already been reported for other intertidal and subtidal gastropods (Wieser 1980, Gäde et al. 1984, Donovan et al. 1999) and bivalves (Vial et al. 1992, Simpendörfer et al. 1995, 1997). The onset of anaerobiosis during prolonged air exposure has also been detected in the blue mussel Mytilus edulis by means of direct calorimetry (Shick et al. 1983, 1986).

Alanine was the predominant anaerobic end product during prolonged air exposure at elevated temperatures in Littorina saxatilis. Interestingly, L- and D-alanine were accumulated in equimolar amounts in the foot muscle tissue of $L$. saxatilis. Generally, free D-alanine is rarely found in molluscan tissues (de Zwaan 1991). Its occurrence was reported for the first time in brackish water and intertidal bivalves Corbicula japonica, Tapes philippinarum and Meretrix lamarckii (Matsushima et al. 1984) but not in Mytilus edulis or Crassostrea gigas, in which only L-alanine was found (de Zwaan 1991). This difference was related to the absence/presence of alanine racemase in these species (Matsushima et al. 1984). These authors suggested that alanine racemase activity, which is also found in some sedimentburying polychaetes and sipunculids (Schöttler et al. 1983, Pörtner et al. 1986), is characteristic of infaunal species. However, accumulation of both stereoisomers of alanine in L. saxatilis suggests that this enzyme may also be present in typically epibenthic species.

It is worth mentioning that alanine accumulation is also a typical response to increased osmolarity of the external medium in marine molluscs (Kinne 1971, Berger 1986). Hence, the main function of alanine accumulation during air exposure in intertidal invertebrates may be iso-osmotic intracellular regulation rather than anaerobic energy provision (Baginski \& Pierce 1975, Wieser 1980). However, direct comparison of cellular responses to anoxia and increased salinity in intertidal molluscs reveals marked differences between the 2 processes (Baginski \& Pierce 1978). During environmental anaerobiosis, alanine accumulation is accompanied by succinate accumulation and aspartate depletion, while the total pool of free amino acids (FAAs) remains unchanged (Baginski \& Pierce 1978, Ellington 1981, Gäde et al. 1984, Churchill \& Storey 1989, Brooks et al. 1991, Storey \& Churchill 1995, this study). In contrast, concentrations of both alanine and aspartate, as well as other non-essential amino acids, strongly increase during acclimation to high salinity, and succinate concentration does not change (Kinne 1971, Baginski \& Pierce 1978, Durand 
et al. 1999). Moreover, comparison of anoxic incubations with and without desiccation stress in 4 littorinid species showed that alanine accumulation was similar under both conditions (Kooijman et al. 1982). In our study, alanine accumulation was considerably lower (or altogether absent) in North Sea Littorina saxatilis, despite higher rates of water loss in these specimens compared to their White Sea counterparts. Hence, alanine accumulation during air exposure in intertidal molluscs seems to be unrelated to the need for maintenance of the osmotic balance. This is probably due to the fact that water is evenly lost from extracellular and intracellular compartments during air exposure in molluscs (Arad et al. 1992, 1993), thus reducing the necessity for iso-osmotic cell volume regulation.

Despite significant anaerobic end-product accumulation, the main energy supplying pathways in Littorina saxatilis were aerobic, with aerial oxygen consumption accounting for $>95 \%$ of the total ATP turnover during air exposure at elevated temperatures. Anaerobiosis contributed no more than $1-2 \%$ of the total ATP turnover during prolonged air exposure in $L$. saxatilis. This is not due to the incomplete assay of the anaerobic end products, since we tested for the most of the anaerobic end products (succinate, D- and L-alanine, D- and L- lactate, propionate and acetate) known for marine molluscs and found only accumulation of succinate and D- and L-alanine. Besides these anaerobic end products, marine invertebrates are also known to produce opines during functional anaerobiosis and exercise (Grieshaber \& Kreutzer 1987, Hammen \& Bullock 1991, Donovan et al. 1999) and to a smaller extent during environmental hypoxia (Kreutzer et al. 1989, Livingstone 1991, Donovan et al. 1999). However, previous studies have shown that opines usually do not accumulate during prolonged environmental anaerobiosis in intertidal molluscs (Eberlee et al. 1983, Gäde et al. 1984, Sukhotin \& Pörtner 1999, Sokolova et al. $2000 \mathrm{~b})$, so that the underestimation of anaerobic $M_{\mathrm{ATP}}$ due to the absence of opine detection should be negligible. In contrast to L. saxatilis, aerobic respiration accounted for $28-36 \%$ and $45 \%$ of total heat dissipation during air exposure in intertidal and subtidal blue mussels, respectively (Shick et al. 1983, 1986). This discrepancy may be attributed to differences in morphological adaptation to air breathing in these 2 species. The typical mid- to low-shore dweller Mytilus edulis lacks specialised air-breathing organs and consumes atmospheric oxygen using gills, whereas the high intertidal species $L$. saxatilis possesses a vestigial ctenidium and a strongly vascularised mantle cavity which may serve as a 'lung' during air exposure (Hyman 1967, Fretter \& Graham 1976). Thus, L. saxatilis may be better adapted to breathing air and thus less dependent on anaerobiosis during air exposure than $M$. edulis.
Similarly, high-shore barnacles Jehlius cirratus mostly relied on aerobic metabolism during air exposure at low tide, and succinate fermentation was a more important metabolic strategy in mid- to low-intertidal bivalves Perumytilus purpuratus and Mytilus chilensis (Simpendörfer et al. 1995). An increase of aerobic capacities in air towards high-shore levels was also reported in several species of intertidal gastropods, which in some groups (e.g. Archaeogastropoda and Mesogastropoda) was linked to morphological adaptations to air breathing in high-shore species (McMahon 1988).

Comparisons of metabolic rates in specimens from different shore levels suggest that an improved ability for metabolic rate depression may be a common strategy of survival under harsh environmental conditions (de Zwaan \& van den Thillart 1985, Storey \& Storey 1990, de Zwaan et al. 1991, Grieshaber et al. 1994, Hand \& Hardewig 1996, Sokolova et al. 2000b). Indeed, despite high aerobic capacity, the rates of aerobic metabolism and ATP turnover in dried air comprised only ca $80 \%$ of the aquatic aerobic rates in White Sea Littorina saxatilis. With only a small contribution from anaerobic metabolism (1-2\%), this suggests a general depression of metabolic rate in air in these snails. Although this decrease was statistically insignificant due to the high individual variation in oxygen consumption rates in this study ( $t$-test, $\mathrm{p}=$ $0.23)$, a general decline of respiration rate in dried air by $20-60 \%$ compared to aquatic oxygen consumption is well documented for several high-shore populations of L. saxatilis, spending 70-95\% of their total time out of water (McMahon \& Russel-Hunter 1977, McMahon 1988). In contrast, aerial respiration rates of less resistant North Sea snails were ca $110-125 \%$ of the rates of aquatic oxygen consumption, indicating that these specimens were incapable of metabolic depression under these conditions. Total (aerobic and anaerobic) rate of ATP turnover was negatively correlated with survival time in L. saxatilis from different latitudes and shore levels (Pearson's $\mathrm{R}=-0.747$ ), although this correlation was non-significant due to the small number of compared groups ( $\mathrm{N}=4, \mathrm{p}=0.25)$. Interestingly, an increased resistance to prolonged air exposure was also associated with lower rates of anaerobic endproduct accumulation and lower anaerobic ATP turnover rates in high-shore L. saxatilis from the White Sea as compared to their low-shore counterparts. In contrast, North Sea snails from different shore levels with similar resistance to prolonged air exposure, demonstrated only small (usually non-significant) and inconsistent differences in anaerobic metabolic rates.

The onset of anaerobiosis during prolonged air exposure in Littorina saxatilis indicates transition to a timelimited situation characterised by negative changes in 
cell energy status of the foot muscle tissue. Initial (control) values of PLA and ATP concentrations in the foot muscle tissues of $L$. saxatilis were in the range of values previously reported for Littorina spp. (Sokolova et al. 2000b and references therein). Air exposure at elevated temperature led to a pronounced and rapid degradation of the high-energy compounds (ATP and PLA) in White Sea and North Sea L. saxatilis, suggesting that ATP production was not able to keep pace with the energy demand under these conditions and/or that a drop in intracellular $\mathrm{pH}_{\mathrm{i}}$ occurred leading to ATP and PLA depletion. After $48 \mathrm{~h}$ of air exposure, when a considerable onset of mortality was detected in the experimental specimens, tissue levels of ATP, PLA and $R_{\text {PLA }}$ dropped to $1.4-1.7 \mu \mathrm{mol} \mathrm{g}^{-1}$ wet wt, $1.5-1.8 \mu \mathrm{mol}$ $\mathrm{g}^{-1}$ wet wt and 35-45\%, respectively. However, these values exceed the minimum concentrations of highenergy compounds associated with the onset of mortality in L. saxatilis during prolonged anaerobiosis under hypo-osmotic stress by a factor of 2-3 (Sokolova et al. 2000b), indicating that the impaired energy status is not responsible for mortality of $L$. saxatilis during prolonged air exposure.

It is worth noting that the most resistant group (highshore snails from the White Sea) tended to maintain lower levels of ATP and PLA in both control and air exposure conditions than in North Sea periwinkles and low-shore snails from the White Sea. Higher control concentrations of high-energy phosphates (ATP and especially PLA) correlated with lower resistance to prolonged air exposure were also previously reported for subtidal Mytilus edulis from the White Sea as compared to their intertidal counterparts (Sukhotin \& Pörtner 1999). At the same time, high-shore Littorina saxatilis from the White Sea had significantly higher concentrations of fermentable substrate, L-aspartate, than their conspecifics from low-shore levels or from the North Sea. Survival times $\left(\mathrm{LT}_{50}\right)$ during prolonged air exposure at $30^{\circ} \mathrm{C}$ were significantly and positively correlated with the initial concentration of L-aspartate in the muscle tissue $(r=0.975, p<0.025, N=4)$ and negatively correlated with control PLA levels ( $\mathrm{r}=$ $-0.994, \mathrm{p}<0.01, \mathrm{~N}=4$ ) in L. saxatilis. This indicates that the higher resistance to prolonged emersion in intertidal molluscs may be correlated with a lower dependence on phosphagen reserves for buffering ATP and with increased substrate stores.

In conclusion, our data show that adaptation to prolonged air exposure at elevated temperatures, which may occur at high-shore levels during summer low tide, does not involve increased anaerobic capacity in Littorina saxatilis. Instead, improved water conservation abilities and metabolic rate depression combined with increased stores of fermentable substrate seem to be important for survival of the snails during pro- longed emersion. A decrease in metabolic rate in air may be linked to the necessity to reduce the gaping inevitably associated with water loss. There is no evidence that impaired cell energy status is a direct reason for mortality in $L$. saxatilis during prolonged air exposure at elevated temperatures. In contrast, higher resistance to prolonged air exposure is correlated with decreased phosphagen stores and possibly reflects less dependence on phosphagen fermentation for buffering of the intracellular ATP pool in more resistant snails. Within a population, differences in physiological responses to prolonged air exposure at elevated temperatures are much more conspicuous between snails from different shore levels in the White Sea than in the North Sea. This reflects local environmental conditions at the 2 study sites, with much stronger and more extreme contrasts between high- and low-shore conditions at the White Sea as compared to the generally milder (micro-) climatic situation at the North Sea site. These data suggest that extreme and unpredictable conditions of the high-shore level may impose strong selection pressure on high-shore inhabitants, leading to considerable physiological (Sokolova et al. 2000a, this study) and genetic differentiation (Johannesson \& Johannesson 1989, Johannesson et al. $1995 \mathrm{a}, \mathrm{b})$ even within a single species, and agree with the notion that performance limits evolve especially rapidly when populations are exposed to short, extreme, selective bouts rather than chronic, sublethal stress (Parsons 1987, Trussell 1997, Mongold et al. 1999).

Acknowledgements. This study was supported by the Alexander von Humboldt Fellowship to I.M.S., which is gratefully acknowledged. Thanks are also due to Dr E. Sokolov for writing a program for pairwise comparison of linear regressions, to Dr R. Scharek for kindly providing temperature data for Helgoland area and to Drs A. Sommer and A. Sukhotin for their invaluable help during the White Sea expedition. All experiments comply with the current laws of the countries (Germany and Russia) where they were performed.

\section{LITERATURE CITED}

Arad Z, Goldenberg S, Heller J (1992) Intraspecific variation in resistance to desiccation and climatic gradients in the distribution of the land snail Xeropicta vestalis. J Zool 226: 643-656

Arad Z, Goldenberg S, Heller J (1993) Intraspecific variation in resistance to desiccation and climatic gradients in the distribution of the bush-dwelling land snail Trochoidea simulata. J Zool 229:249-265

Babkov AI (1998) Hydrology of the White Sea. Zoological Institute of RAS Publ, St. Petersburg (in Russian)

Baginski RM, Pierce SK Jr (1975) Anaerobiosis: a possible source of osmotic solute for high-salinity acclimation in marine molluscs. J Exp Zool 62:589-598

Baginski RM, Pierce SK Jr (1978) A comparison of amino acid 
accumulation during high salinity adaptation with anaerobic metabolism in the ribbed mussel, Modiolus demissus demissus. J Exp Zool 203:419-428

Berger VJA (1986) Adaptations of marine molluscs to changes of environmental salinity. Nauka, Leningrad (in Russian)

Bergmeyer HU (1985a) Methods of enzymatic analysis. Vol VI. Metabolites 1: Carbohydrates. Vol VI. Metabolites 3: Lipids, Amino Acids and Related Compounds. VCH Verlagsgesellschaft, Weinheim

Bergmeyer HU (1985b) Methods of enzymatic analysis. Vol VI. Metabolites 1: Carbohydrates. Vol VIII. Metabolites 3: Lipids, Amino Acids and Related Compounds. VCH Verlagsgesellschaft, Weinheim

Bowen CE (1984) Facultative anaerobiosis in Haliotis (ormer/ abalone): Pyruvate kinase and phosphoenolpyruvate carboxykinase activities. Comp Biochem Physiol 77B: 197-200

Britton JC (1995) The relationship between position on shore and shell ornamentation in two size-dependent morphotypes of Littorina striata, with an estimate of vaporative water loss in these morphotypes and in Melaraphe neritoides. Hydrobiologia 309:129-142

Britton JC, McMahon RF (1990) The relationship between vertical distribution, evaporative water loss, behaviour, and some morphometric parameters in four species of rocky intertidal gastropods from Hong Kong. In: Morton B (ed) The marine flora and fauna of Hong Kong and Southern China 2. Vol 3. Behaviour, morphology, physiology and pollution. Hong Kong University Press, Hong Kong, p 1153-1171

Broekhuysen GJ (1940) A preliminary investigation of the importance of desiccation, temperature and salinity as factors controlling the vertical zonation of certain intertidal marine gastropods in False Bay, South Africa. Trans R Soc S Afr 128:255-291

Brooks SPJ, de Zwaan A, van den Thillart G, Cattani O, Cortesi P, Storey KB (1991) Differential survival of Venus gallina and Scapharca inaequivalvis during anoxic stress: covalent modification of phosphofructokinase and glycogen phosphorylase during anoxia. J Comp Physiol 161B: 207-212

Brown AC (1960) Desiccation as a factor influencing the distribution of some South African Gastropoda from intertidal rocky shores. Port Acta Biol 8B:11-23

Churchill TA, Storey KB (1989) Intermediary energy metabolism during dormancy and anoxia in the land snail Otala lactea. Physiol Zool 62:1015-1030

Cleland JD, McMahon RF (1986) Upper thermal limit of nine intertidal gastropod species from a Hong Kong rocky shore in relation to vertical distribution and desiccation associated with evaporative cooling. In: Morton B (ed) Proceedings of the 2nd International Workshop on the Malacofauna of Hong Kong and Southern China. Hong Kong University Press, Hong Kong, p 1141-1152

Davies PS (1969) Physiological ecology of Patella. III. Desiccation effects. J Mar Biol Assoc UK 49:291-304

de Vooys CGN (1980) Anaerobic metabolism in sublittoral living Mytilus galloprovincialis Lam. in the Mediterranean. II. Partial adaptation of pyruvate kinase and phosphoenolpyruvate carboxykinase. Comp Biochem Physiol 65B: 513-518

de Zwaan A (1983) Carbohydrate catabolism in bivalves. In: Hochachka PW (ed) The Mollusca. Vol 1: Metabolic biochemistry and molecular biomechanics. Academic Press, New York, p 137-175

de Zwaan A (1991) Molluscs. In: Bryant C (ed) Metazoan life without oxygen. Chapman and Hall, London, p 186-217 de Zwaan A, van den Thillart G (1985) Low and high power output modes of anaerobic metabolism: invertebrate and vertebrate strategies. In: Gilles R (ed) Circulation, respiration and metabolism. Springer-Verlag, Berlin, p 166-192

de Zwaan A, Cortesi P, van den Thillart G, Roos J, Storey KB (1991) Differential sensitivities to hypoxia by two anoxiatolerant marine molluscs: a biochemical analysis. Mar Biol 1111:343-351

Donovan D, Baldwin J, Carefoot T (1999) The contribution of anaerobic energy to gastropod crawling and a re-estimation of minimum costs of transport in the abalone, Haliotis kamtschatkana (Jonas). J Exp Mar Biol Ecol 235:273-284

Durand F, Chausson F, Regnault M (1999) Increases in tissue free amino acid levels in response to prolonged emersion in marine crabs: an ammonia-detoxifying process efficient in the intertidal Carcinus maenas but not in the subtidal Necora puber. J Exp Biol 202:2191-2202

Eberlee JC, Storey JM, Storey KB (1983) Anaerobiosis, recovery from anoxia, and the role of strombine and alanopine in the oyster Crassostrea virginica. Can J Zool 61:2682-2687

Ellington WR (1981) Energy metabolism during hypoxia in the isolated, perfused venticle of the whelk, Busycon contrarium Conrad. J Comp Physiol 142:457-464

Fretter V, Graham A (1976) A functional anatomy of invertebrates. Academic Press, London

Gäde G, Carlsson KH (1984) Purification and characterisation of octopine dehydrogenase from the marine nemertean Cerebratulus lacteus (Anopla: Heteronemerta): comparison with scallop octopine dehydrogenase. Mar Biol 79: $39-45$

Gäde G, Carlsson KH, Meinardus G (1984) Energy metabolism in the foot of the marine gastropod Nassa mutabilis during environmental and functional anaerobiosis. Mar Biol 80:49-56

Garland T, Adolph SC (1994) Why not to do two-species comparative studies: limitations on inferring adaptation. Physiol Zool 67:797-828

Gibbs AG (1999) Laboratory selection for the comparative physiologist. J Exp Biol 202:2709-2718

Grieshaber MK, Kreutzer U (1987) Opine formation in marine invertebrates. Zool Beitr 30:205-229

Grieshaber M, Kronig E, Koormann R (1978) A photometric estimation of phospho-L-arginine, arginine and octopine using homogeneous octopine dehydrogenase isozyme 2 from the squid, Loligo vulgaris Lam. Hoppe-Seyler's Z Physiol Chem 359:133-136

Grieshaber MK, Hardewig I, Kreutzer U, Pörtner HO (1994) Physiological and metabolic responses to hypoxia in invertebrates. Rev Physiol Biochem Pharmacol 125:43-147

Hammen CS, Bullock RC (1991) Opine oxidoreductases in brachiopods, bryozoans, phoronids and molluscs. Biochem Syst Ecol 19:263-269

Hand SC, Hardewig I (1996) Downregulation of cellular metabolism during environmental stress: mechanisms and implications. Annu Rev Physiol 58:539-563

Hardewig I, Addink ADF, Grieshaber MK, Pörtner HO, van den Thillart G (1991) Metabolic rates at different oxygen levels determined by direct and indirect calorimetry in the oxyconformer Sipunculus nudus. J Exp Biol 157:143-160

Hickel W, Eickhoff E, Spindler H, Berg J, Raabe T, Mueller R (1997) Auswertung von Langzeit-Untersuchungen von Nährstoffen und Phytoplankton in der Deutschen Bucht. Umweltbundesamt, Berlin, Texte 23/97

Houlihan DF (1979) Respiration in air and water of three mangrove snails. J Exp Mar Biol Ecol 41:143-161

Houlihan DF, Innes AJ, Dey DG (1981) The influence of man- 
tle cavity fluid on the aerial oxygen consumption of some intertidal gastropods. J Exp Mar Biol Ecol 49:57-68

Hull SL, Grahame J, Mill P (1999) Heat stability and activity levels of aspartate aminotransferase and alanine aminotransferase in British Littorinidae. J Exp Mar Biol Ecol 237: $255-270$

Hyman LH (1967) The invertebrates. Mollusca I. Vol VI. McGraw-Hill Book Company, New York

Innes AJ, Houlihan DF (1985) Aquatic and aerial oxygen consumption of cool temperate gastropods: a comparison with some mediterranean species. Comp Biochem Physiol 82A: 105-109

Janke K (1997) Die Macrofauna und ihre Verteilung im Nordost-Felswatt von Helgoland. Helgol Meeresunters 40:1-55

Johannesson K, Johannesson B (1989) Differences in allele frequencies of AAT between high- and mid-rocky shore populations of Littorina saxatilis (Olivi) suggest selection in this enzyme locus. Genet Res 54:7-11

Johannesson K, Johannesson B, Lundgren U (1995a) Strong natural selection causes microscale allozyme variation in a marine snail. Proc Natl Acad Sci USA 92:2602-2606

Johannesson K, Rolan-Alvarez E, Ekendahl A (1995b) Incipient reproductive isolation between two sympatric morphs of the intertidal snail Littorina saxatilis. Evolution 49: 1180-1190

Kaliberdina MV (1998) Analysis of physiological peculiarities and population structure of the gastropod Littorina saxatilis along the vertical shore gradient of environmental conditions on White Sea intertidal. BSc thesis, St. Petersburg State University (in Russian)

Kinne O (1971) Salinity. Animals. Invertebrates. In: Kinne O (ed) Marine ecology, Vol 1, Part 2. Wiley, London, p 821-996

Klimant I, Meyer V, Kuehl M (1995) Fiber-optic oxygen microsensors, a new tool in aquatic biology. Limnol Oceanogr 40:1159-1165

Kooijman D, van Zoonen H, Zurburg W, Kluytmans J (1982) On the aerobic and anaerobic energy metabolism of Littorina species in realtion to the pattern of intertidal zonation. In: Addink ADF, Sponk N (eds) Exogenous influences on metabolic and neural control. Pergamon Press, Oxford, p 134-135

Kreutzer U, Siegmund BR, Grishaber M (1989) Parameters controlling opine formation during muscular activity and environmental hypoxia. J Comp Physiol B 159:617-628

Kronberg I (1990) Heat production in Littorina saxatilis Olivi and Littorina neritoides L. (Gastropoda: Prosobranchia) during an experimental exposure to air. Helgol Meeresunters 44:125-134

Livingstone DR (1991) Origins and evolution of pathways of anaerobic metabolism in the animal kingdom. Am Zool 31: $522-534$

Lyzen IM, Sukhotin AA, Sergievsky SO (1992) Influence of infection by trematode parthenitae on the water respiration rate of the intertidal mollusc Littorina obtusata. Parazitologiya 26:521-523 (in Russian)

Marsden ID, Weatherhead MA (1998) Effects of aerial exposure on oxygen consumption by the New Zealand mussel Perna canaliculus (Gmelin, 1791) from an intertidal habitat. J Exp Mar Biol Ecol 230:15-29

Matsushima O, Katayama H, Yamada K, Kado Y (1984) Occurrence of free D-alanine and alanine racemase activity in bivalve molluscs with special reference to intracellular osmoregulation. Mar Biol Lett 5:217-225

McMahon BR (1988) Physiological responses to oxygen depletion in intertidal animals. Am Zool 28:30-53
McMahon RF (1990) Thermal tolerance, evaporative water loss, air-water oxygen consumption and zonation of intertidal prosobranchs: a new synthesis. Hydrobiologia 193: 241-260

McMahon RF (1992) Respiratory response to temperature and hypoxia in intertidal gastropods from the Texas coast of the Gulf of Mexico. In: Grahame J, Mill PJ, Reid DG (eds) Proceedings of the 3rd International Symposium on Littorinid Biology. Malacological Society of London, London, p 45-59

McMahon RF, Britton JC (1985) The relationship between vertical distribution, thermal tolerance, evaporative water loss rate and behaviour on emergence in six species of mangrove gastropods from Hong Kong. In: Morton B, Dudgeon D (eds) Proceedings of the 2nd International Workshop on the Malacofauna of Hong Kong and Southern China, Vol 2. Hong Kong University Press, Hong Kong, p 563-582

McMahon RF, Russell-Hunter WD (1977) Temperature relations of aerial and aquatic respiration in six littoral snails in relation to their vertical zonation. Biol Bull 152: 182-198

McQuaid CD, Scherman PA (1988) Thermal stress in a high shore environment: morphological and behavioural adaptations of the gastropod Littorina africana. In: Chelazzi G, Vannini M (eds) Behavioural adaptation to intertidal life. Plenum Press, New York, p 213-224

Mongold JA, Bennett AF, Lenski RE (1999) Evolutionary adaptation to temperature. VII. Extension of the upper thermal limit of Escherichia coli. Evolution 53:386-394

Newell RC (1979) Biology of intertidal animals. Marine Ecological Surveys Ltd, Faversham

Parsons PA (1987) Evolutionary rates under environmental stress. Evol Biol 21:311-347

Pörtner HO, Kreutzer U, Siegmund B, Heisler N, Grieshaber MK (1984) Metabolic adaptation of the intertidal worm Sipunculus nudus to functional and environmental hypoxia. Mar Biol 79:237-247

Pörtner HO, Vogeler S, Grieshaber MK (1986) Recovery from anaerobiosis in the intertidal worm Sipunculus nudus. I. Restoration of aerobic, steady state energy metabolism. J Exp Biol 122:37-50

Radford EP (1964) The physics of gases. In: Fenn WO, Rahn $\mathrm{H}$ (eds) Handbook of physiology, Vol 1, Sect 3. Respiration. American Physiological Society, Washington, DC, p 125-152

Raffaelli D, Hawkins S (1996) Intertidal ecology. Chapman \& Hall, London

Sanders BM, Hope C, Pascoe VM, Martin LS (1991) Characterisation of the stress protein response in two species of Colisella limpets with different temperature tolerances. Physiol Zool 64:1471-1489

Sandison E (1966) The oxygen consymption of some intertidal gastropods in relation to zonation. J Zool 149:163-173

Schöttler U, Wienhausen G, Zebe E (1983) The mode of energy production in the lugworm Arenicola marina at different oxygen concentrations. J Comp Physiol 149B: $547-555$

Shick JM, de Zwaan A, de Bont AMTh (1983) Anoxic metabolic rate in the mussel Mytilus edulis L. estimated by simultaneous direct calorimetry and biochemical analysis. Physiol Zool 56:56-63

Shick JM, Gnaiger E, Widdows J, Bayne BL, de Zwaan A (1986) Activity and metabolism in the mussel Mytilus edulis L. during intertidal hypoxia and aerobic recovery. Physiol Zool 59:627-642

Shick JM, Widdows J, Gnaiger E (1988) Calorimetric studies 
of behaviour, metabolism and energetics of sessile intertidal animals. Am Zool 28:161-181

Simpfendörfer RW, Vial VM, Lopez DA, Verdala M, Gonzalez ML (1995) Relationship between the aerobic and anaerobic metabolic capacities and the vertical distribution of three intertidal sessile invertebrates: Jehlius cirratus (Darwin) (Cirripedia), Perumytilus purpuratus (Lamarck) (Bivalvia) and Mytilus chilensis (Hupe) (Bivalvia). Comp Biochem Physiol 111B:615-623

Simpendörfer R, Vial MV, Monsalve A, González ML (1997) Piruvato quinasa muscular de Perumytilus purpuratus: Evidencias de la presencia de la enima fosforilada en terreno durante todo el ciclo de marea. Rev Biol Mar Oceanogr 32:117-126

Sokal RR, Rohlf FJ (1995) Biometry (the principle and practice of statistics in biological research), 3rd edn. WH Freeman and Company, New York

Sokolova IM (1997) Populational aspects of adaptation of the intertidal gastropods Littorina saxatilis to low salinity. PhD thesis, Zoological Institute of Russian Academy of Sciences, St. Petersburg (in Russian)

Sokolova IM, Pörtner HO (2001) Temperature effects on key metabolic enzymes in Littorina saxatilis and L. obtusata from different latitudes and shore levels. Mar Biol 139: $113-126$

Sokolova IM, Granovitch AI, Berger VJa, Johannesson K (2000a) Intraspecific physiological variability of the gastropod Littorina saxatilis related to the vertical shore gradient in the White and North Seas. Mar Biol 137:297-308

Sokolova IM, Bock C, Pörtner HO (2000b) Resistance to freshwater exposure in White Sea Littorina spp. I. Anaerobic metabolism and energetics. J Comp Physiol B 170:91-103

Stirling HP (1982) The upper temperature tolerance of prosobranch gastropods of rocky shores at Hong Kong and Dar Es Salaam, Tanzania. J Exp Mar Biol Ecol 63:133-144

Storey KB, Churchill TA (1995) Metabolic responses to an-

Editorial responsibility: Otto Kinne (Editor),

Oldendorf/Luhe, Germany oxia and freezing by the freeze tolerant marine mussel Geukensia demissus. J Exp Mar Biol Ecol 188:99-114

Storey KB, Storey JM (1990) Metabolic rate depression and biochemical adaptation in anaerobiosis, hibernation and estivation. Q Rev Biol 65:145-174

Sukhotin AA, Pörtner HO (1999) Habitat as a factor involved in the physiological response to environmental anaerobiosis of White Sea Mytilus edulis. Mar Ecol Prog Ser 184: 149-160

Tomanek L, Somero GN (1999) Evolutionary and acclimationinduced variation in the heat-shock pesponses of congeneric marine snails (genus Tegula) from different thermal habitats: implications for limits of thermotolerance and biogeography. J Exp Biol 202:2925-2936

Tomanek L, Somero GN (2000) Time course and magnitude of synthesis of heat-shock proteins in congeneric marine snails (genus Tegula) from different tidal heights. Physiol Biochem Zool 73:249-256

Trussell GC (1997) Phenotypic selection in an intertidal snail: effects of a catastrophic storm. Mar Ecol Prog Ser 151: 73-79

Urbakh VYU (1964) Biometric methods. Nauka, Moscow (in Russian)

Vial MV, Simpendörfer RW, López DA, González ML, Oelckers K (1992) Metabolic responses of the intertidal mussle Perumytilus purpuratus (Lamarck) in emersion and immersion. J Exp Mar Biol Ecol 159:191-201

Wieser W (1980) Metabolic end products in three species of marine gastropods. J Mar Biol Assoc UK 60:175-180

Yipp MW, Dudgeon D, Cha MW (1986) Respiratory adaptations and survival of three high-intertidal littorinids (Gastropoda) from Hong Kong rocky shores. In: Morton B (ed) The marine flora and fauna of Hong Kong and Southern China 2. Vol 3. Behaviour, morphology, physiology and pollution. Hong Kong University Press, Hong Kong, p 1041-1054

Submitted: February 27, 2001; Accepted: August 7, 2001 Proofs received from author(s): October 10, 2001 